DOI: https://doi.org/10.24127/ajpm.v9i2.2782

\title{
PENGEMBANGAN LEMBAR KEGIATAN SISWA MENGGUNAKAN PENDEKATAN PENDIDIKAN MATEMATIKA REALISTIK
}

\author{
Heriyadi $^{1}$, Rully Charitas Indra Prahmana ${ }^{2}$
}

\author{
${ }^{1}$ STKIP Melawi, Melawi, Indonesia \\ ${ }^{2 *}$ Universitas Ahmad Dahlan, Yogyakarta, Indonesia \\ E-mail: $\quad$ heriyadipmat@gmail.com ${ }^{1)}$ \\ rully.indra@mpmat.uad.ac.id ${ }^{2 *}$
}

Received 28 April 2020; Received in revised form 21 June 2020; Accepted 24 June 2020

\begin{abstract}
Abstrak
Penelitian ini bertujuan untuk menghasilkan Lembar Kegiatan Siswa (LKS) menggunakan pendekatan Pendidikan Matematika Realistik pada materi kubus dan balok yang valid, praktis, dan memiliki efek potensial terhadap kemampuan literasi matematis siswa. Metode penelitian yang digunakan dalam penelitian ini adalah design research tipe development studies, yang terdiri atas dua tahap yaitu prelimininary design dan formative evaluation. Teknik pengumpulan data yang digunakan meliputi lembar penilaian, walkthrough, dokumen dan tes kemampuan literasi matematika. Penelitian ini melibatkan siswa kelas VIII SMP Muhammadiyah Banguntapan untuk menghasilkan LKS menggunakan pendekatan pendidikan matematika realistik pada materi kubus dan balok yang valid, praktis, dan memiliki efek potensial terhadap kemampuan literasi matematika. Hasil penelitian menunjukkan bahwa LKS telah valid dari kualitas materi maupun kualitas media dengan kriteria baik, berdasarkan komentar ahli pada tahapan expert review dan one to one. Selanjutnya, implementasi LKS pada tahap small group dan field test menunjukkan kepraktisan LKS dengan kriteria baik. Hal ini terlihat dari LKS yang dapat dikenali siswa, mudah dibaca, serta siswa dapat dengan mudah menggunakan alat dan bahan yang diberikan untuk menyelesaikan setiap tahapan kegiatan pada LKS. Terakhir, efek potensial dari LKS diperoleh pada tahapan field test yang menunjukkan bahwa siswa mampu mengerjakan soal level 4 dari 6 level kemampuan literasi matematika, sehingga LKS ini berpotensi untuk menumbuhkan kemampuan literasi siswa sampai level 4.
\end{abstract}

Kata kunci: Lembar kerja siswa; design research; literasi matematika; kubus dan balok.

\begin{abstract}
This study aims to produce a Student Worksheet (SW) using a Realistic Mathematics Education approach for cube and cuboid subjects that is valid, practical, and has a potential effect on students' mathematical literacy abilities. The research method used in this research is design research with the type of development studies, which consists of two stages, namely preliminary design and formative evaluation. Data collection techniques used include assessment sheets, walkthroughs, documents and tests of mathematical literacy abilities. This study involved eighth-grade students of SMP Muhammadiyah Banguntapan to produce worksheets using a realistic mathematics education approach for cube and cuboid subject that is valid, practical, and has a potential effect on mathematical literacy abilities. The results show that the worksheets were valid in terms of subject and media quality with a good criterion, based on expert comments at the expert review and one to one stage. Furthermore, the implementation of $S W$ in the small group and field test stages shows the practicality of $S W$ with a good criterion. It can be seen from the worksheets that can be recognized by students, easy to read, and students can easily use the tools and materials provided by researchers to complete each stage of activities in the worksheets. Finally, the potential effect of the worksheet is obtained at the field test stage which shows that students are able to work on level 4 questions of mathematical literacy ability so that this worksheet has the potential to emerge students' literacy skills up to level 4.
\end{abstract}

Keywords: Student worksheet; design research; mathematics literacy; cube and cuboid. 
DOI: https://doi.org/10.24127/ajpm.v9i2.2782

\section{PENDAHULUAN}

Standar isi pada pembelajaran matematika menjelaskan bahwa tujuan pembelajaran matematika di sekolah sudah memperhatikan aspek-aspek dalam kemampuan literasi matematika (Anisah, Zulkardi, \& Darmawijoyo, 2011; Damayanti, Suarsana, Suryawan, 2017; Buyung \& Dwijanto, 2017). Selanjutnya, OECD (2016) mendefinisikan kemampuan literasi matematika sebagai suatu kemampuan individu untuk merumuskan, menerapkan, dan menafsirkan matematika dalam berbagai konteks, meliputi penalaran matematis, menggunakan konsep matematika, prosedur, fakta dan alat untuk menggambarkan, serta menjelaskan dan memprediksi fenomena. Sejalan dengan hal tersebut, Sari (2015) menjelaskan bahwa kemampuan literasi matematika sebagai kemampuan seseorang untuk merumuskan, dan menafsirkan matematika dalam berbagai konteks masalah kehidupan sehari-hari secara efisien. Sehingga, kemampuan literasi matematika menjadi salah satu kompetensi utama dalam melakukan kegiatan sehari-hari yang diimplementasikan pada tujuan pembelajaran matematika di sekolah.

Namun, pentingnya kemampuan literasi matematika ini ternyata tidak sejalan dengan prestasi kemampuan literasi matematika siswa Indonesia di tingkat Internasional. Hal ini ditunjukan pada hasil survei yang dilakukan oleh Programme for International Student Assessment (PISA), yang menyatakan bahwa kemampuan literasi matematika siswa di Indonesia masih rendah (OECD, 2018). Pada hasil PISA terbaru pada tahun 2018, menunjukkan bahwa hanya sekitar $1 \%$ dari siswa Indonesia yang mampu memodelkan permasalahan yang kompleks secara matematis (OECD, 2019).

Salah satu upaya yang dapat dilakukan oleh tenaga pendidik untuk meningkatkan kemampuan literasi matematika siswa adalah melakukan inovasi pembelajaran matematika dan mengembangkan instrumen pembelajaran (Wardono \& Kurniasih, 2015). Selanjutnya, sejumlah peneliti telah mendokumentasikan hasil penelitiannya yang menyatakan bahwa suatu pembelajaran yang menggunakan pendekatan Pendidikan Matematika Realistik (PMR) memiliki dampak positif terhadap kemampuan literasi matematika siswa (Budiono, 2014; Kusuma, Wardono, \& Winarti, 2016; Wardono \& Kurniasih, 2015; Lestari, Prahmana, \& Wiyanti, 2016; Mangelep \& Kaunang, 2018). Di sisi lain, Wijaya (2012) mengemukakan bahwa kelebihan pendekatan PMR adalah menekankan learning by doing, hal ini sejalan dengan pernyataan Freudental bahwa "matematika merupakan suatu bentuk aktivitas manusia". Lebih lanjut, Wijaya (2012) melalui pendekatan PMR, siswa terlebih dahulu diperkenalkan dengan permasalahan real, yang artinya disini juga dapat dibayangkan oleh siswa, melalui prinsip penemuan kembali, siswa secara aktif untuk menemukan kembali konsep matematika dengan bimbingan guru, proses penemuan kembali ini menggunakan konsep matematisasi (matematika formal). Hal ini sejalan dengan cara mengukur kemampuan literasi matematika siswa dalam tes PISA (Wardono \& Kurniasih, 2015). Oleh karena itu, pembelajaran dengan menggunakan pendekatan PMR dinilai efektif dapat meningkatkan kemampuan literasi matematika siswa.

Beberapa faktor yang 
matematika meliputi kualitas dan metode pengajaran serta ketersediaan media belajar/bahan ajar di sekolah (Syawahid \& Putrawangsa, 2017). Selain itu, rendahnya diseminasi terkait literasi matematika juga menyebabkan kurangnya bahan ajar yang digunakan untuk meningkatkan kemampuan literasi matematika siswa (Khikmiyah \& Midjan, 2016). Selanjutnya, perangkat pembelajaran yang inovatif berbasis pendekatan pendidikan matematika realistik, termasuk didalamnya berupa multimedia pembelajaran matematika (Wahyuni, Masykur, \& Pratiwi, 2019) dan Lembar Kegiatan Siswa (LKS) dapat meningkatkan kemampuan literasi matematika (Wati, Zulkardi, Susanti, 2015; Wardono \& Kurniasih, 2015; Sholahudin, 2018; Andari \& Komsiatun, 2018). Ketersediaan LKS yang dibuat oleh guru atau kelompok guru, adalah implementasi dari penyusunan rencana pelaksanaan pembelajaran, dan dampaknya dapat dirasakan oleh semua siswa (Haryani, Wardani, \& Prasetya, 2016). Oleh karena itu, diperlukan pengembangan bahan ajar berupa LKS dalam pembelajaran matematika berbasis pendekatan PMR, baik digunakan oleh guru ataupun siswa agar dapat membantu meningkatkan literasi matematika siswa.

Salah satu fondasi dalam kemampuan literasi matematika adalah geometri (OECD, 2016). Pada tingkatan Sekolah Menengah Pertama (SMP) objek kajian geometri terdapat pada materi kubus dan balok kelas VIII (Kemdikbud, 2017). Dalam penelitianya, Mahdiansyah dan Rahmawati (2014) menyatakan bahwa pada objek geometri (konteks ruang dan bentuk) memiliki rata-rata literasi matematika siswa yang terendah dibanding rata-rata lainnya, yaitu 25,8 . Oleh sebab ini, penelitian ini memilih objek kajian geometri pada materi kubus dan balok di kelas VIII SMP.

Terakhir, hasil wawancara terhadap guru matematika di SMP Muhammadiyah Banguntapan, menunjukkan bahwa belum ada bahan ajar berupa LKS matematika yang menggunakan pendekatan PMR, serta sumber belajar yang secara khusus memfasilitasi siswa dalam meningkatkan kemampuan literasi matematika pada materi kubus dan balok. Selain itu, siswa dan guru menceritakan bahwa mereka membutuhkan bahan ajar berupa LKS matematika menggunakan pendekatan PMR pada materi kubus dan balok yang dapat digunakan dalam proses belajarmengajar untuk meningkatkan kemampuan literasi siswa.

Di sisi lain, sejumlah penelitian sebelumnya, mengembangkan perangkat pembelajaran menggunakan pendekatan PMR untuk materi bangun datar (Febriya, Pranata, \& Apriliya, 2015; Shoffa, 2016; Basuki \& Wijaya, 2018) atau pada materi bangun ruang menggunakan konteks aktivitas seharihari (Efuansyah \& Wahyuni, 2018) dan meningkatkan hasil belajar (Santi, Sugiarti, \& Kristiana, 2015; Ose, 2017), namun belum ada yang fokus mengembangkan LKS pada materi Kubus dan Balok menggunakan konteks lampion berpendekatan PMR untuk melihat kemampuan literasi matematis siswa. Sehingga, penelitian ini difokuskan pada pengembangan suatu bahan ajar matematika berupa LKS matematika berpendekatan PMR pada materi Kubus dan Balok dengan menggunakan konteks lampion untuk siswa Kelas VIII SMP dalam upaya meningkatkan kemampuan literasi matematis siswa. 
DOI: https://doi.org/10.24127/ajpm.v9i2.2782

\section{METODE PENELITIAN}

Penelitian ini merupakan penelitian design research tipe development studies dengan dua tahapan yaitu tahap preliminary evaluation dan formative evaluation (Tessmer, 1993; Prahmana, 2017). Pada tahap preliminary evaluation, analisis masalah dan mendesain solusi dari permasalahan menjadi fokus utama. Pada tahap formative evaluation, solusi dari permasalahan yang telah dirancang pada tahap desain. Evaluasi solusi dari permasalahan melalui proses prototyping yang meliputi selfevaluation, expert review, one-to-one, small group, dan field test. Secara skematis alur pengembangan LKS dan instrumen penilaian dinyatakan pada Gambar 1.

Subjek penelitian meliputi siswa kelas VIII A dan VIII B di SMP Muhammadiyah Banguntapan. Siswa dimintai respon terhadap LKS yang dikembangkan melalui angket kepraktisan. Selanjutnya, setelah mengikuti pembelajaran menggunakan LKS dengan pendekatan PMR, siswa mengerjakan soal tes untuk mengetahui efek potensial LKS terhadap kemampuan literasi matematika mereka.

\section{Low Resistance to $\longrightarrow$ Revision High Resistence to revesion}

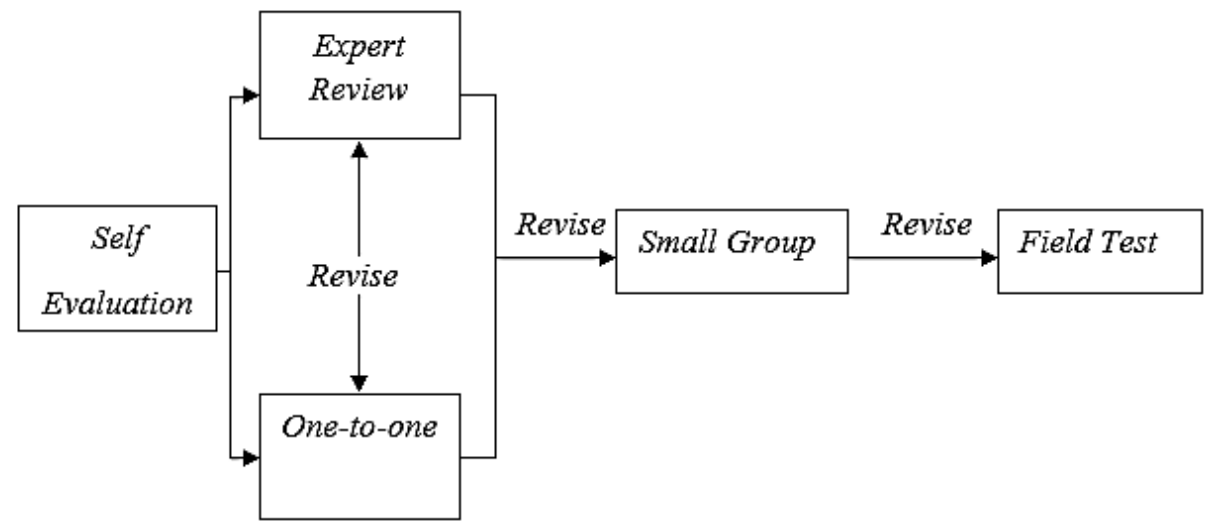

Gambar 1. Alur Desain Formative Evaluation (Tessmer, 1993)

Teknik pengumpulan data pada penelitian ini menggunakan beberapa instrumen yang meliputi lembar penilaian kualitas instrumen, walkthrough, dokumen, dan soal tes kemampuan literasi matematika. Teknik analisis data untuk lembar penilaian kualitas instrumen menggunakan angket dengan skala Likert (1 sampai 5). Adapun tabel penilaian kualitas produk dapat dilihat pada Tabel 1.

Data walkthrough merupakan data yang diperoleh dari hasil tahapan expert review, one-to-one, dan small group dalam bentuk masukan dan saran terhadap LKS yang dikembangkan. Analisis masukan dan saran yang diberikan expert review untuk menyimpulkan bagian mana saja yang direvisi. Masukan dan saran expert review selanjutnya dibuat dalam bentuk kalimat deskriptif, untuk kemudian dianalisis sebagai bahan revisi dari prototipe LKS, sehingga diperoleh LKS yang valid dan praktis. 
DOI: https://doi.org/10.24127/ajpm.v9i2.2782

Tabel 1. Kriteria penilaian kualitas produk.

\begin{tabular}{ccc}
\hline No & Skor & Kriteria \\
\hline 1 & $X>\bar{X}_{l}+1,80 S B_{i}$ & Sangat Baik \\
\hline 2 & $\bar{X}_{i}+0,60 S B_{i}<X \leq \bar{X}_{i}+1,80 S B_{i}$ & Baik \\
\hline 3 & $\bar{X}_{i}-0,60 S B_{i}<X \leq \bar{X}_{i}+0,60 S B_{i}$ & Cukup \\
\hline 4 & $\bar{X}_{i}-1,80 S B_{i}<X \leq \bar{X}_{i}-0,60 S B_{i}$ & Kurang \\
\hline 5 & $X \leq \bar{X}_{l}-1,80 S B_{i}$ & Sangat Kurang \\
\hline
\end{tabular}

Keterangan:

$\bar{X}_{i} \quad=$ Rata-rata ideal

$\bar{X}_{i} \quad=\frac{1}{2} x($ skor maksimal ideal + skor minimum ideal $)$

$S B_{i} \quad=$ Simpangan baku ideal

$S B_{i}=\frac{1}{6} x($ skor maksimal ideal - skor minimum ideal $)$

dimana:

Skor maksimal ideal $=$ jumlah butir kriteria $\times$ skor tertinggi

Skor minimum ideal $=$ jumlah butir kriteria $\times$ skor terendah

Pada analisis dokumen instrumen penelitian dianalisis dan disesuaikan dengan kurikulum 2013, karakteristik pendekatan PMR, dan indikator kemampuan literasi matematika. Untuk mengetahui efek potensial dari LKS yang dikembangkan menggunakan tes kemampuan literasi matematika yang disesuaikan dengan level kemampuan literasi matematika, yang mana terdapat 6 level dengan kriteria soal masingmasing level berbeda. Analisis dilakukan dengan 2 tahapan yaitu mentabulasi data tes hasil kemampuan literasi matematika menggunakan pedoman penskoran dan menyesuaikan hasil tes kemampuan literasi matematika siswa dengan level kemampuan siswa.

\section{HASIL DAN PEMBAHASAN Preliminary Evaluation}

Pada tahap ini peneliti melakukan analisis terhadap kurikulum, materi dan karakteristik siswa dengan hasil meliputi: (1) lembar kegiatan siswa yang digunakan dalam proses belajar mengajar sudah sesuai dengan
Kompetensi Inti dan Kompetensi Dasar beserta indikator pencapaianya disesuaikan dengan kurikulum pendidikan pemerintah Indonesia (Kurikulum K-13); (2) Lembar kegiatan siswa (LKS) yang digunakan oleh guru belum mengukur kemampuan literasi matematika. Pada materi belum banyak mengaitkan pengetahuan dengan dunia nyata siswa; dan (3) Dari segi karakteristik siswa yaitu siswa membutuhkan LKS untuk memudahkan siswa dan guru dalam proses kegiatan belajar mengajar. Berdasarkan hasil observasi awal diputuskan untuk menentukan siswa kelas VIII A sebagai subyek uji coba tahap one-to-one dan small group. Selanjutnya, siswa kelas VIII B sebagai subyek uji coba dalam field test yang berjumlah 26 orang dengan tingkat kemampuan heterogen. Langkah selanjutnya, merancang solusi dari permasalahan yang meliputi LKS, materi, indikator pencapaian kompetensi, tujuan pembelajaran serta instrumen penilaian kualitas produk yang disesuaikan berdasarkan kurikulum 2013 dan pendekatan PMR. 
Hasil dari tahapan ini, dinamakan prototipe 1 .

\section{Formative Evaluation}

Tahapan ini terdiri dari 5 fase besar, yaitu self-evaluation, expert review, one-to-one, small group, dan field test. Pada setiap fase memiliki maksud dan tujuan tertentu. Fase pertama sampai keempat merupakan proses validasi LKS yang dikembangkan, sehingga muncul beberapa prototipe LKS sampai akhirnya, mendapatkan prototipe final yang diujikan pada fase field test untuk melihat efek potensial dari LKS tersebut terhadap kemampuan literasi siswa.

\section{Self Evaluation}

Hasil evaluasi pada tahapan ini tidak banyak mengalami perubahan yang signifikan, selain pada pendesainan ulang cover dari LKS untuk disesuaikan dengan materi dan tema yang dipilih.

\section{Expert Review}

Uji kevalidan LKS pada prototipe I yang dievaluasi oleh 3 orang dosen pakar pendekatan PMR dan 2 orang dosen ahli materi geometri. Para expert meliputi: (1) Dr. Bagus Ardi Saputro, M.Pd, proses validasi dilakukan secara mail review pada 12 Desember 2018.
Beliau adalah seorang dosen di Universitas PGRI Semarang, selain itu beberapa publikasi riset beliau adalah mengenai penelitian pengembangan termasuk diantaranya pada bidang geometri; (2) Zetra Hainul Putra, Ph.D., proses validasi dilakukan secara mail review pada 17 Desember 2018. Beliau adalah seorang dosen di Universitas Riau, selain itu fokus riset beliau adalah terkait pendekatan PMR; (3) Shintia Revina, Ph.D., proses validasi dilakukan secara mail review pada 18 Desember 2018. Beliau adalah seorang peneliti di SMERU Research Institute di Jakarta, selain itu fokus riset beliau adalah terkait pendekatan PMR; (4) Dr. Hongki Julie, M.Si, proses validasi dilakukan secara face-to-face pada 13 Desember 2018. Beliau adalah seorang dosen di Universitas Sanata Dharma, selain itu fokus riset beliau diantaranya adalah mengenai pendekatan PMR; (5) Dr. Julan Hernadi, M.Si, Proses validasi dilakukan secara face-to-face pada 26 Desember 2018. Beliau adalah seorang dosen di Universitas Muhammadiyah Ponorogo dan Universitas Ahmad Dahlan, selain itu fokus riset beliau terkait bidang Geometri. Secara keseluruhan hasil perhitungan kriteria angket validasi dari expert review disajikan dalam Tabel 2.

Tabel 2. Hasil angket kriteria kualitas materi dan kualitas media.

\begin{tabular}{clcccc}
\hline \multirow{2}{*}{ No } & \multirow{2}{*}{ Validator } & \multicolumn{2}{c}{ Kualitas Materi } & \multicolumn{2}{c}{ Kualitas Media } \\
\cline { 3 - 5 } & & Skor & Kriteria & Skor & Kriteria \\
\hline 1 & Dr. Bagus Ardi Saputro, M.Pd & 52 & Baik & 64 & Baik \\
2 & Zetra Hainul Putra, Ph.D & 60 & Baik & 79 & Sangat Baik \\
3 & Dr. Hongki Julie, M.Si & 54 & Baik & 63 & Baik \\
4 & Dr. Julan Hernadi, M.Si & 57 & Baik & 70 & Baik \\
5 & Shintia Revina Ph. D & 53 & Baik & 69 & Baik \\
& Jumlah & 276 & & 345 & \\
& Rata-Rata & 55,2 & Baik & 69 & Baik \\
\hline
\end{tabular}


DOI: https://doi.org/10.24127/ajpm.v9i2.2782

Beberapa bagian yang mengalami perubahan signifikan setelah proses expert review, meliputi bagian pendahuluan, Kegiatan 1.1. Penggunaan Masalah Kontekstual, Kegiatan 1.4 Interaktivitas dan Keterkaitan, dan Latih Dirimu. Bagian pendahuluan merupakan materi prasyarat sebelum penggunaan LKS. Pada pendahuluan prototipe 1 direvisi dari segi tampilan dan cara penyampaian materi prasyarat yang diperlukan sebelum penggunaan LKS. Revisi lainnya yaitu memberi penamaan kubus sesuai arah jarum jam, memulai penyampaian dengan bentuk kubus terlebih dahulu, baru dilanjutkan dengan contoh kubus dalam kehidupan sehari-hari dan dilanjutkan dengan mengenalkan istilah persegi satuan. Selanjutnya, pada kegiatan penggunaan masalah kontekstual yang bertujuan melibatkan peserta didik secara aktif, mengeksplorasi ide-ide, dan strategi penyelesaian masalah yang diberikan. Pada prototipe 1 ditampilkan seperti pada Gambar 2.

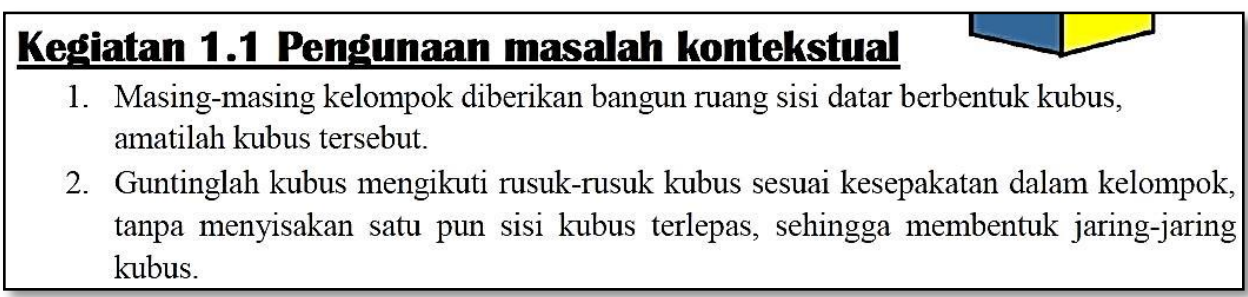

Gambar 2. Kegiatan 1.1

Setelah proses expert review, pada kegiatan ini diperbaiki, dengan catatan bahwa kegiatan penggunaan konteks haruslah disesuaikan dengan situasi nyata yang pernah dialami oleh peserta didik. Termasuk diantaranya dalam pembuatan lampion berbentuk kubus dari kertas berwarna. Peneliti membangun situasi ini agar penggunaan masalah menjadi menarik bagi siswa. Hasil perbaikan dapat dilihat pada Gambar 3.

Kegiatan 1.4. Interaktivitas dan Keterkaitan bertujuan untuk membangun interaksi dalam pembelajaran antara guru dan siswa yang berupa diskusi antar sesama siswa dan guru, tanya jawab, serta mengevaluasi variasi solusi dari pemecahan masalah serta mengaitkan materi yang dipelajari, antara konsep satu dengan konsep yang lainnya untuk digunakan sebagai satu keterkaitan dalam penyelesaian masalah. Setelah proses expert review, pada kegiatan ini diperbaiki menjadi kegiatan penyelesaian masalah Yadi dan temantemannya yang ditampilkan pada kegiatan sebelumnya, yaitu kegiatan 1.1 .

Pada proses pembuatan lampion siswa diminta menentukan berapa banyak jumlah kertas berwarna yang dibutuhkan untuk membuat 1 lampion. Setelah mengetahui berapa banyaknya jumlah kertas yang ada, selanjutnya siswa menentukan jumlah keseluruhan biaya yang dikeluarkan untuk menyelesaikan tugas prakarya tersebut. Keterkaitan disini terjadi antara mata pelajaran matematika dan prakarya, sedangkan dari segi konsep pemecahan masalah berkaitan dengan materi aritmatika sosial dan perbandingan senilai. 


\section{Kegiatan 1.1 Penggunaan Masalah Kontekstual}

Yadi dan teman-temanya diberikan tugas prakarya oleh gurunya membuat lampion berbentuk kubus warna warni. Lampion tersebut masing-masing memiliki 3 warna yaitu bewarna hijau, biru dan kuning. Untuk mengetahui jumlah kertas warna yang akan digunakan, terlebih dahulu yadi dan teman-temannya harus mengetahui luas permukaan lampion yang akan dibuat.
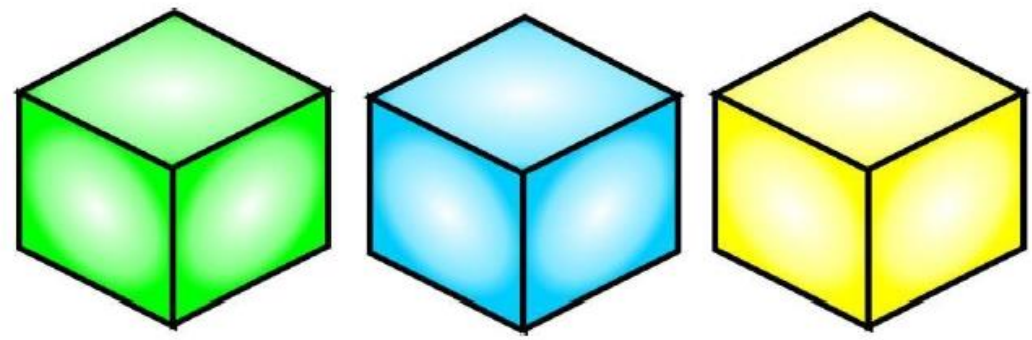

Mari kita bantu yadi dan teman-temannya menyelesaikan permasalahan tersebut secara efisien satu diantara nya adalah dengan melakukan kegiatan-kegiatan berikut ini:

4. Masing-masing kelompok diberikan persegi satuan dari kardus.

5. Buatlah jaring-jaring kubus dari persegi satuan tersebut. Masing-masing kelompok membuat jaring-jaring kubus yang berbeda antara kelompok satu dan kelompok lainnya.

Gambar 3. Hasil Revisi Kegiatan 1.1

Terakhir, pada LKS yang dikembangkan penamaan soal latihan menggunakan istilah "Latih Dirimu". Soal latihan ini bertujuan untuk melihat sejauh mana siswa memahami LKS dan memahami soal kontekstual yang berkaitan dengan materi luas permukaan dan volume kubus dan balok. Setelah proses expert review, beberapa soal mengalami perubahan yang signifikan. Perbaikan yang dilakukan adalah dengan mengganti soal yang ada dengan soal yang baru. Hal ini dikarenakan soal diangap kurang familiar dengan kondisi pengalaman nyata siswa.

Hasil keseluruhan perbaikan terhadap prototipe 1 dinamakan prototipe 2. Dalam hal ini prototipe 2 dapat dikatakan sudah valid secara kualitatif, berdasarkan hasil perbaikan, masukan, dan saran pada tahapan expert review serta valid secara kuantitatif berdasarkan angket dengan kriteria "baik" (lihat Tabel 2). Selanjutnya. prototipe 2 diujicobakan pada tahapan one to one.

\section{One-to-One}

Pada tahap ini, prototipe 2 diberikan kepada tiga orang siswa kelas VIII A SMP Muhammadiyah Banguntapan dengan tingkat kemampuan kognitif yang berbedabeda, kegiatan ini dilaksanakan pada tanggal 8 Januari 2019 dengan tujuan agar peneliti dapat mengamati kendala dan respon siswa ketika mengerjakan LKS. Ketiga orang siswa tersebut diberi nama NF, NFA, dan RF.

Pada tahapan ini masukan dan saran siswa secara garis besar hanya meminta pendahuluan didahulukan sebelum memasuki tahapan kegiatan yang ada dalam LKS. Hasil yang 
didapat pada tahap ini tidak terlalu signifikan, sehingga, setelah perbaikan, peneliti mengambil keputusan untuk melanjutkan ke tahapan small group.

\section{Small Group}

Pada tahap ini, prototipe 2 diujicobakan kepada enam orang siswa dari kelas VIII A SMP Muhammadiyah Banguntapan yang bukan merupakan bagian dari subyek penelitian utama untuk pengujian LKS pada fase field test. Tahap ini dilaksanakan pada 9 Januari 2019, uji coba dilakukan dengan tujuan melihat keterbacaan LKS dan melihat respon siswa kelas kecil terhadap LKS sebelum digunakan pada tahap field test.

Pada pengerjaan kegiatan 1.1 penggunaan masalah kontekstual, siswa menyusun persegi satuan yang berbahan dasar kardus untuk membentuk jaringjaring kubus, setelah terbentuk jaringjaring kubus siswa menggambarkan bentuk yang didapatkan pada kegiatan pemodelan. Pada kegiatan 1.3 keaktifan siswa, siswa saling berdiskusi untuk menentukan apakah luas permukaan kubus dapat dikatakan sama dengan luas jaring-jaring kubus, serta apakah ada kaitannya dengan luas persegi satuan yang disampaikan pada bagian pendahuluan.

Pada kegiatan 1.4 Interaktivitas dan keterkaitan, siswa menyelesaikan permasalahan kontekstual pada Kegiatan 1.1 yaitu untuk membantu Yadi dan teman-temannya terkait pembuatan lampion dan berapa biaya yang harus dikeluarkan secara keseluruhan. Pada tahap ini siswa mengaitkan permasalahan tersebut dengan menggunakan konsep luas permukaan kubus yang memiliki enam sisi dan konsep perbandingan pada aritmatika sosial mengenai harga.
Siswa membagi luas kertas disesuaikan dengan panjang rusuk dari lampion, yang mana luas kertas berwarna yaitu $60 \mathrm{~cm} \quad$ x $40 \mathrm{~cm}$ disesuaikan dengan panjang rusuk yaitu $20 \mathrm{~cm}$. Sehingga, 1 kertas berwarna dapat dibagi menjadi 6 bagian yang sama luasnya yaitu $20 \mathrm{~cm}$ x $20 \mathrm{~cm}$. Jadi, siswa dapat menyimpukan bahwa 1 kertas akan cukup untuk membuat 1 lampion.

Tahapan selanjutnya, siswa diberikan angket respon siswa dengan tujuan untuk melihat sejauh mana respon siswa terhadap kepraktisan penggunaan LKS. Hasil yang diperoleh disajikan pada Tabel 3 .

Tabel 3. Hasil angket respon siswa small group.

\begin{tabular}{clcl}
\hline No & $\begin{array}{l}\text { Nama } \\
\text { Siswa }\end{array}$ & Skor & Kriteria \\
\hline 1 & SM1 & 49 & Baik \\
2 & SM2 & 49 & Baik \\
3 & SM3 & 56 & Sangat Baik \\
4 & SM4 & 44 & Baik \\
5 & SM5 & 49 & Baik \\
6 & SM6 & 33 & Cukup \\
& Jumlah & 280 & \\
& Rata-Rata & 46,67 & Baik \\
\hline
\end{tabular}

*Keterangan: SM= Siswa Small Group

Tabel 3 menunjukkan bahwa skor rata-rata yaitu 46,67 yang artinya tingkat kepraktisan penggunaan LKS masuk kriteria "Baik". Selain melihat kriteria kepraktisan, peneliti juga menganalisis saran dan masukan siswa sebagai perbaikan dari prototipe 2 sebelum diujicobakan pada tahap field test. Sejumlah saran dan masukan dari siswa dideskripsikan pada Tabel 4. 
DOI: https://doi.org/10.24127/ajpm.v9i2.2782

Tabel 4. Masukan dan saran siswa small group.

\begin{tabular}{|c|c|}
\hline No & Masukan dan Saran \\
\hline 1 & $\begin{array}{l}\text { LKS nya menarik, dengan } \\
\text { persoalan lebih menantang }\end{array}$ \\
\hline 2 & $\begin{array}{l}\text { Untuk materi kebanyakan pak, } \\
\text { kalau bisa dibagi menjadi } 2 \\
\text { pertemuan saja }\end{array}$ \\
\hline 3 & $\begin{array}{l}\text { Kalimat perintah disetiap perintah } \\
\text { kegiatan agak disederhanakan }\end{array}$ \\
\hline 4 & $\begin{array}{l}\text { Masalah pada soal membuat saya } \\
\text { memahami tujuan mempelajari } \\
\text { kubus dan balok }\end{array}$ \\
\hline 5 & $\begin{array}{l}\text { Untuk petunjuk setiap LKS } \\
\text { diperjelas lagi pak! }\end{array}$ \\
\hline 6 & $\begin{array}{lr}\text { Saya cukup } & \text { paham dengan } \\
\text { permasalahan } & \text { kontekstual } \\
\text { kegiatan } 1.1 & \end{array}$ \\
\hline 7 & $\begin{array}{l}\text { Dengan adanya LKS materi kubus } \\
\text { dan balok lebih mudah dipahami }\end{array}$ \\
\hline
\end{tabular}

Berdasarkan masukan dan saran siswa pada small group, sejumlah perbaikan yang signifikan terhadap prototipe 2 , diantaranya yaitu petunjuk penggunaan LKS dibuat dengan tujuan agar siswa mudah memahami dan menggunakan LKS. Setelah fase small group, petunjuk penggunaan diperjelas dengan menambahkan beberapa item petunjuk guna lebih memudahkan siswa dalam menggunakan dan mengerjakan LKS. Selain itu, Pada beberapa kegiatan di LKS ada beberapa kalimat perintah atau instruksi yang dianggap kurang dimengerti oleh siswa.

Berdasarkan masukan dan saran dari siswa pada saat small group, maka perbaikan dilakukan dengan menyederhanakan bahasa pada Kegiatan 1.2. Hasil perbaikan pada prototipe 2, setelah melalui tahapan one-to-one dan small group, selanjutnya disebut sebagai prototipe 3. Dalam hal ini prototipe 3 sudah dapat dikatakan valid dan praktis secara kualitatif, berdasarkan masukan dan saran, kemudahan penggunaan LKS, dan siswa dapat mengerjakan tiap perintah yang terdapat dalam LKS.

Secara kuantitatif kevalidan dan kepraktisan berdasarkan perhitungan angket yaitu dengan kriteria "Baik" (lihat Tabel 3). Untuk selanjutnya, prototipe 3 diuji coba pada tahapan field test untuk melihat efek potensial LKS ini pada kemampuan literasi matematis siswa.

\section{Field Test}

Pada tahapan ini, prototipe 3 diujicobakan kepada siswa kelas VIII B SMP Muhammadiyah Banguntapan yang merupakan subyek penelitian yang terdiri dari 26 orang siswa. Berdasarkan hasil ujicoba pada small grup, peneliti membagi tahapan ini menjadi 2 tahapan yaitu tahapan pertama dilaksanakan pada tanggal 10 Januari 2019 dengan melakukan observasi secara langsung keterlaksanaan penggunaan LKS oleh guru dalam pembelajaran dan tahapan kedua dilaksanakan pada tanggal 14 Januari 2019 yaitu dengan memberikan soal tes untuk melihat efek potensial penggunaan LKS terhadap kemampuan literasi matematika siswa.

$$
\text { Pada tahapan pertama }
$$
pelaksanaan pembelajaran, jumlah siswa yang hadir yaitu 22 orang. Pada tahap ini, peneliti bertindak sebagai observer dan membantu guru menjelaskan makna perintah pada LKS, apabila ada kalimat yang kurang dipahami oleh siswa dalam pengerjaan LKS.

Pada akhir tahap ini, peneliti memberikan angket respon siswa dengan tujuan untuk melihat tingkat kriteria kepraktisan penggunaan LKS serta saran dan masukan setelah pembelajaran selesai dilaksanakan. Hasil dari angket tersebut disajikan pada Tabel 5. 
DOI: https://doi.org/10.24127/ajpm.v9i2.2782

Tabel 5. Hasil angket respon siswa pada fase field test.

\begin{tabular}{clcl}
\hline No & Nama & Skor & Kriteria \\
& Siswa & & \\
\hline 1 & FT1 & 49 & Baik \\
2 & FT2 & 56 & Sangat \\
& & & Baik \\
3 & FT3 & 48 & Baik \\
4 & FT4 & 52 & Sangat \\
& & & Baik \\
5 & FT5 & 51 & Sangat \\
6 & FT6 & 45 & Baik \\
7 & FT7 & 42 & Baik \\
8 & FT8 & 46 & Baik \\
9 & FT9 & 50 & Baik \\
10 & FT10 & 50 & Baik \\
11 & FT11 & 48 & Baik \\
12 & FT12 & 54 & Sangat \\
& & & Baik \\
13 & FT13 & 46 & Baik \\
14 & FT14 & 55 & Sangat \\
& & & Baik \\
15 & FT15 & 47 & Baik \\
16 & FT16 & 43 & Baik \\
17 & FT17 & 46 & Baik \\
18 & FT18 & 48 & Baik \\
19 & FT19 & 44 & Baik \\
20 & FT20 & 50 & Baik \\
21 & FT21 & 48 & Baik \\
22 & FT22 & 45 & Baik \\
& Jumlah & 1063 & \\
& Rata-rata & 48,31 & Baik \\
\hline Keterangan: FT= Siswa & Field st \\
\hline
\end{tabular}

*Keterangan: FT= Siswa Field Test

Pada Tabel 5, terlihat bahwa hasil kriteria kepraktisan penggunaan LKS pada kelas field test berada pada kriteria "Baik". Selanjutnya, pasca pembelajaran menggunakan LKS menggunakan pendekatan PMR pada materi kubus dan balok, sejumlah saran dan masukan melalui respon siswa dapat dilihat pada Tabel 6.

Tabel 6. Respon siswa pada fase field test terhadap LKS.

\begin{tabular}{ll}
\hline No & \multicolumn{1}{c}{ Masukan dan Saran } \\
\hline 1 & $\begin{array}{l}\text { Pelajaran hari ini sangat seru dan } \\
\text { menyenangkan. }\end{array}$ \\
2 & $\begin{array}{l}\text { Dengan adanya LKS mempermudah } \\
\text { saya dalam memahami materi. }\end{array}$ \\
3 & $\begin{array}{l}\text { Saya bisa memahami materi dalam } \\
\text { LKS ini. }\end{array}$ \\
4 & Sangat seru dan sukses terus ya, see
\end{tabular}
you next time.

5 Membuat belajar lebih menarik dan membuat saya lebih memahami tentang kubus dan balok, sehingga membuat saya lebih semangat untuk mempelajari tentang pelajaran yang saya terima hari ini.

6 Saya dapat memahami soal.

7 Belajar sambil bermain sangat mengasyikan.

8 Saya bisa menambah ilmu dan wawasan.

9 Seru banggat.

10 Membuat LKS lebih menarik lagi.

11 Belajar sambil bermain dengan menggunakan LKS.

12 Saya bisa memahami materi dalam LKS ini.

13 LKS dibuat lebih bagus dan rapi lagi dan pembelajaran menyenangkan.

14 Membuat LKS lebih menarik lagi.

15 Dengan adanya LKS berpendekatan pendidikan matematika realistik saya terbantu dalam memahami kubus dan balok.

16 Belajar sambil bermain sangat mengasyikan.

17 Soal dalam LKS dapat membantu saya memahami materi dan mempermudah saya memahami materi.

Pada tahapan kedua, jumlah siswa yang hadir sebanyak 15 orang. Selanjutnya siswa diberikan soal tes 
DOI: https://doi.org/10.24127/ajpm.v9i2.2782

dengan tujuan untuk mengetahui efek potensial penggunaan LKS terhadap kemampuan literasi matematika siswa. Soal tes yang diujikan pada tahap kedua ini berjumlah 6 soal dengan 6 level indikator kemampuan literasi matematika. Hasil tes yang diperoleh disajikan dalam Tabel 7.

Tabel 7 Hasil tes kemampuan literasi matematika.

\begin{tabular}{|c|c|c|c|c|c|c|c|c|}
\hline \multirow[t]{2}{*}{ No } & \multirow{2}{*}{$\begin{array}{l}\text { Nama } \\
\text { Siswa }\end{array}$} & \multicolumn{6}{|c|}{ Kemampuan Literasi Matematika } & \multirow{2}{*}{$\begin{array}{c}\text { Tingkat } \\
\text { Kemampuan } \\
\text { Kognitif }\end{array}$} \\
\hline & & $\begin{array}{c}\text { Level } \\
1\end{array}$ & $\begin{array}{c}\text { Level } \\
2\end{array}$ & $\begin{array}{c}\text { Level } \\
3\end{array}$ & $\begin{array}{c}\text { Level } \\
4\end{array}$ & $\begin{array}{c}\text { Level } \\
5\end{array}$ & $\begin{array}{c}\text { Level } \\
6\end{array}$ & \\
\hline 1. & FT1 & $\checkmark$ & $\checkmark$ & $\checkmark$ & & & & Sedang \\
\hline 2. & FT2 & $\checkmark$ & $\sqrt{ }$ & & & & & Sedang \\
\hline 3. & FT4 & $\checkmark$ & $\checkmark$ & & & & & Rendah \\
\hline 4. & FT6 & $\checkmark$ & $\sqrt{ }$ & $\sqrt{ }$ & & & & Sedang \\
\hline 5. & FT7 & $\checkmark$ & $\checkmark$ & & & & & Rendah \\
\hline 6. & FT8 & $\checkmark$ & $\checkmark$ & $\checkmark$ & $\sqrt{ }$ & & & Sedang \\
\hline 7. & FT9 & $\checkmark$ & $\sqrt{ }$ & $\checkmark$ & $\checkmark$ & & & Tinggi \\
\hline 8. & FT11 & $\checkmark$ & $\sqrt{ }$ & $\checkmark$ & $\checkmark$ & & & Tinggi \\
\hline 9. & FT13 & $\checkmark$ & $\checkmark$ & $\checkmark$ & $\checkmark$ & & & Tinggi \\
\hline 10. & FT14 & $\checkmark$ & $\sqrt{ }$ & & & & & Sedang \\
\hline 11. & FT15 & $\checkmark$ & $\checkmark$ & $\checkmark$ & $\checkmark$ & & & Tinggi \\
\hline 12. & FT16 & $\checkmark$ & $\checkmark$ & $\checkmark$ & & & & Sedang \\
\hline 13. & FT17 & $\checkmark$ & $\checkmark$ & $\checkmark$ & & & & Sedang \\
\hline 14. & FT18 & $\checkmark$ & $\checkmark$ & $\checkmark$ & $\checkmark$ & & & Tinggi \\
\hline 15. & FT22 & $\checkmark$ & $\checkmark$ & $\checkmark$ & $\checkmark$ & & & Tinggi \\
\hline
\end{tabular}

*Keterangan:

Level 1: Siswa dapat menjawab pertanyaan yang melibatkan konteks yang dikenal dimana semua informasi relevan dan pertanyaannya didefinisikan secara jelas

Level 2: $\quad$ Siswa dapat menafsirkan dan mengenali situasi dalam konteks yang membutuhkan kesimpulan langsung

Level 3: Siswa dapat melaksanakan prosedur dengan jelas, termasuk prosedur yang memerlukan keputusan secara berurutan

Level 4: Siswa dapat bekerja secara efektif dalam situasi konkret namun kompleks yang mungkin melibatkan kendala dalam membuat asumsi

Level 5: Siswa dapat mengembangkan dan bekerja dengan model untuk situasi yang kompleks, mengidentifikasi kendala dan menentukan asumsi

Level 6: Siswa dapat mengkonseptualisasikan, menggeneralisasi dan memanfaatkan informasi berdasarkan penyelidikan dan pemodelan situasi masalah yang kompleks, dan dapat menggunakan pengetahuan mereka dalam konteks yang relatif tidak standar (di atas rata-rata) 
DOI: https://doi.org/10.24127/ajpm.v9i2.2782

Pada Tabel 7 terlihat bahwa efek potensial setelah penggunaan LKS terhadap kemampuan literasi matematika yaitu siswa dengan kognitif tinggi rata-rata mampu menyelesaikan sampai level 4 (6 Orang), siswa dengan kognitif sedang, rata-rata mampu menyelesaikan sampai level 3 (7 Orang), dan siswa dengan kognitif rendah rata-rata mampu menyelesaikan sampai level 2 (2 Orang). Kemampuan kognitif didasarkan pada data yang diperoleh dari guru mata pelajaran berdasarkan ranking siswa dikelas.

Selanjutnya, hasil penelitian yang telah dideskripsikan berdasarkan tahapan-tahapan penelitian design research tipe development studies, dibahas secara komprehensif. Pada tahap preliminary evaluation, peneliti melakukan telaah terhadap analisis kurikulum, materi dan karakterstik siswa akan kebutuhan pembelajaran. Melalui wawancara terbuka kepada siswa dan guru serta pengecekan dokumen yang digunakan pada pembelajaran diperoleh hasil bahwa pembelajaran disekolah menggunakan kurilulum 2013 dan siswa membutuhkan LKS yang bisa membantu siswa mengaitkan materi yang dipelajari dengan kondisi nyata, agar pembelajaran dirasa lebih bermakna. Hasil ini digunakan sebagai dasar untuk melanjutkan penelitian ke tahapan desain perangkat pembelajaran yang disebut dengan prototipe 1 .

Pada tahap formative evaluation, prototipe 1 dikumpulkan untuk selanjutnya dievaluasi pada tahapan self evaluation. Hasil pada tahapan ini meliputi LKS menggunakan pendekatan PMR pada materi kubus dan balok, lembar penilaian kualitas produk ahli materi, lembar penilaian kualitas produk ahli media, angket respon siswa, serta soal tes yang digunakan untuk melihat efek potensial LKS terhadap kemampuan literasi matematika. Selanjutnya LKS pada prototipe 1 memasuki tahap expert review, one-toone dan small group. Berdasarkan hasil evaluasi dari expert review dan one-toone, LKS dikatakan valid dari segi materi maupun media yang digunakan dengan kriteria "Baik" yang selanjutnya disebut sebagai prototipe 2 .

Setelah LKS pada prototipe 2 dinyatakan valid, selanjutnya menguji kepraktisan prototipe 2 melalui observasi pada tahap small group. Aspek kriteria kepraktisan dinilai dari angket respon siswa baik dari segi penyajian materi, kegrafikan, dan manfaat. Pada tahap ini 6 orang siswa kelas VIII A dengan kemampuan kognitif tinggi, sedang, dan rendah. Dalam hal ini, siswa dapat memahami perintah tiap kegiatan pada LKS dengan baik. Konteks yang digunakan pada LKS juga dapat dikenali siswa, mudah dibaca, serta siswa dapat dengan mudah menggunakan alat dan bahan yang diberikan untuk menyelesaikan tahap kegiatan pada LKS. Hasil masukan dan saran pada tahap small group digunakan untuk merevisi prototipe 2. Hasil perbaikan dari prototipe 2 selanjutnya disebut dengan prototipe 3 yang valid dan praktis dengan kriteria "Baik".

Prototipe 3 yang valid dan praktis kemudian diujicobakan pada tahap field test. Tahapan field test terbagi menjadi dua tahapan yaitu tahapan pertama observasi secara langsung keterlaksanaan penggunaan LKS oleh guru dalam pembelajaran dan tahapan kedua yaitu dengan memberikan soal tes untuk melihat efek potensial penggunaan LKS terhadap kemampuan literasi matematika siswa. 
DOI: https://doi.org/10.24127/ajpm.v9i2.2782

Berdasarkan hasil tahapan pertama pada field test, tidak ada kendala berarti yang guru alami dalam mengimplementasikan LKS. Pada LKS, setiap kegiatan disesuaikan dengan menggunakan karakteristik pendekatan PMR yang meliputi (1) penggunaan masalah kontekstual, yang mana pemilihan konteks berdasarkan pengalaman siswa dalam mata pelajaran prakarya saat membuat lampion berbentuk kubus dan kotak tisu berbentuk balok; (2) pemodelan, yang mana proses penyelesaian masalah siswa menggunakan persegi satuan untuk membuat jaring-jaring kubus dan kardus kotak makanan untuk membuat jaring-jaring balok; (3) keaktifan siswa, yang mana siswa diberikan kesempatan untuk berdiskusi, mengemukakan ide dan solusi dalam kelompoknya masingmasing; (4) interaktivitas, yang mana terdapat interaksi antara guru dalam mengarahkan kesulitan yang dialami siswa dalam menyelesaikan masalah; dan (5) keterkaitan, yang mana LKS yang dikembangkan memiliki keterkaitan dengan kurikulum 2013, dan kaitannya dengan materi lain yaitu arimatika sosial serta perbandingan senilai. Hal ini sejalan dengan hasil penelitian Zulkardi dan Putri (2010) yang menyatakan bahwa PMR sebagai suatu teori pembelajaran yang berasal dari hal-hal yang 'real' atau pernah dialami siswa, menekankan ketrampilan proses 'doing mathematics', berdiskusi dan berkolaborasi, berargumentasi dengan teman sekelas, sehingga mereka dapat menemukan sendiri (student inventing) sebagai kebalikan dari (teacher telling), dan pada akhirnya menggunakan matematika itu untuk menyelesaikan masalalah baik secara individu maupun kelompok.

Pada tahapan kedua ujicoba field test, diberikan soal tes untuk melihat efek potensial LKS terhadap kemampuan literasi matematika siswa. Hasil yang diperoleh menunjukkan bahwa siswa mampu menjawab soal level 4 pada kemampuan literasi matematika. Hasil ini sesuai dengan hasil penelitian Purwasih, Sari, dan, Agustina (2018) yang menyatakan kemampuan literasi matematika level 3 siswa SMP tergolong sedang, sedangkan pada level 4 tergolong rendah.

Pada soal level 1 dan 2, semua siswa dengan tingkatan level rendah, sedang, dan tinggi mampu menjawab pertanyaan yang melibatkan konteks yang dikenal, yang mana semua informasi relevan dan pertanyaannya didefinisikan secara jelas serta dapat menafsirkan dan mengenali situasi dalam konteks yang membutuhkan kesimpulan langsung. Hasil ini sejalan dengan penelitian Fiad, Suharto, dan Kurniati (2017) yang menyatakan semua siswa pada level kognitif rendah, sedang, dan tinggi mampu menyelesaian setiap indikator kemampuan literasi matematika pada soal level 1 dan 2.

Pada soal level 3 dan 4 siswa dapat melaksanakan prosedur dengan jelas, termasuk prosedur yang memerlukan keputusan secara berurutan dan bekerja secara efektif dalam situasi konkret, namun kompleks yang mungkin melibatkan kendala dalam membuat asumsi. Pada soal ini hanya mampu dijawab oleh siswa dengan level kognitif sedang dan tinggi, hasil ini sejalan dengan penelitian Maulana dan Hasnawati (2016) yang menyatakan bahwa permasalahan tersebut dikarenakan kurangnya kemampuan dasar matematika siswa.

Pada indikator soal level 5 dan 6, tidak ada siswa yang mampu memenuhi untuk mengembangkan dan bekerja 
pada model situasi yang kompleks, mengidentifikasi kendala, dan menentukan asumsi. Siswa juga belum dapat mengkonseptualisasikan, mengeneralisasi, dan memanfaatkan informasi, berdasarkan penyelidikan dan pemodelan situasi masalah yang kompleks, dan dapat menggunakan pengetahuan mereka dalam konteks yang relatif tidak standar (di atas ratarata). Hal ini sejalan dengan penelitian Khoirudin, Setyawati, dan Nursyahida (2017) yang menyatakan bahwa penyebab hal ini, dikarenakan beberapa faktor, yaitu: materi yang dipilih, pembelajaran yang diberikan oleh guru, lingkungan kelas, dukungan lingkungan keluarga, kesiapan dalam pelaksanaan tes, dan kemampuan yang dimiliki setiap siswa sendiri.

Secara keseluruhan pendekatan PMR mampu memberikan efek potensial pada kemampuan literasi matematika siswa dengan tingkat kemampuan kognitif rendah, sedang dan tinggi. Hasil ini sejalan dengan hasil penelitian dari sejumlah peneliti yang menyatakan bahwa pembelajaran yang mengadopsi kelima karakteristik PMR telah terbukti mampu menumbuhkan kemampuan literasi matematis siswa (Budiono, 2014; Kusuma, Wardono, \& Winarti, 2016; Wardono \& Kurniasih, 2015; Lestari, Prahmana, \& Wiyanti, 2016; Mangelep \& Kaunang, 2018; Larasati, Rangga, Rianasari, \& Fitri, 2017; Setyaningsih, Wardono, \& Prabowo, 2017). Sehingga, hasil penelitian ini, menambah bukti empiris yang menyatakan bahwa implementasi kelima karakteristik PMR dalam pembelajaran, salah satunya penggunaan LKS yang berbasis PMR, berpotensi untuk meningkatkan kemampuan literasi matematis siswa. Selain itu, hasil ini juga memberikan kontribusi positif dalam upaya menyediakan alternatif bahan ajar berupa LKS berpendekatan PMR menggunakan konteks lampion yang dekat dengan siswa untuk menumbuhkan kemampuan literasi matematis siswa.

\section{KESIMPULAN DAN SARAN}

LKS menggunakan pendekatan PMR pada materi kubus dan balok kelas VIII SMP terbukti valid, praktis, dan memiliki efek potensial terhadap kemampuan literasi matematis siswa. Hasil penelitian menunjukkan bahwa LKS telah valid dari kualitas materi maupun kualitas media dengan kriteria baik, berdasarkan komentar ahli pada tahapan expert review dan one to one. Selanjutnya, implementasi LKS pada tahap small group dan field test menunjukkan kepraktisan LKS dengan kriteria baik. Terakhir, efek potensial dari LKS diperoleh pada tahapan field test yang menunjukkan bahwa siswa mampu mengerjakan soal level 4 dari 6 level kemampuan literasi matematika, sehingga LKS ini berpotensi untuk menumbuhkan kemampuan literasi siswa sampai level 4.

Sarannya agar para pendidik mulai membiasakan para peserta didik untuk menyelesaikan soal-soal dengan tipe non rutin yang berorientasi pada kemampuan literasi matematis siswa. Selain itu, bagi peneliti lain, yang tertarik untuk mengembangkan LKS berbasis pendekatan PMR, agar dapat mengalokasikan waktu lebih saat proses pembelajaran. Hal ini dikarenakan LKS ini membutuhkan waktu yang lebih lama, dibandingkan dengan pendekatan pembelajaran yang lainnya, sehingga siswa bisa lebih eksploratif selama pembelajaran dan diharapkan dapat berpengaruh terhadap kemampuan literasi matematika mereka hingga level 6. 


\section{DAFTAR PUSTAKA}

Andari, T., \& Komsiatun, E. (2018). Pengembangan LKS Berbasis Pendekatan Realistic Mathematics Education untuk Meningkatkan Kemampuan Matematis Siswa. AKSIOMA: Jurnal Program Studi Pendidikan Matematika, 7(1), 155-160.

Anisah, A., Zulkardi, \& Darmawijoyo. (2011). Pengembangan Soal Matematika Model PISA pada Konten Quantity untuk Mengukur Kemampuan Penalaran Matematis Siswa Sekolah Menengah Pertama. Jurnal Pendidikan Matematika, 5(1), 1-15.

Basuki, W. A., \& Wijaya, A. (2018). The Development of Student Worksheet Based on Realistic Mathematics Education. Journal of Physics: Conference Series, 1097(1), 012112.

Budiono, C. S. (2014). PBM Berorientasi PISA Berpendekatan PMRI Bermedia LKPD Meningkatkan Literasi Matematika Siswa SMP. Unnes Journal of Mathematics Education, 3(3), 210-219.

Buyung, B., \& Dwijanto, D. (2017). Analisis Kemampuan Literasi Matematis melalui Pembelajaran Inkuiri dengan Strategi Scaffolding. Unnes Journal of Mathematics Education Research, 6(1), 112-119.

Damayanti, N. K. A., Suarsana, I. M., \& Suryawan, I. P. P. (2017). Peningkatan Kemampuan Literasi Matematika Siswa melalui Penerapan Collaborative Learning Model. Wahana Matematika dan Sains: Jurnal Matematika, Sains, dan Pembelajarannya, 11(1), 3342.
Efuansyah, E., \& Wahyuni, R. (2018). Pengembangan Bahan Ajar Matematika Berbasis PMRI pada Materi Kubus dan Balok Kelas VIII. Jurnal Derivat: Jurnal Matematika dan Pendidikan Matematika, 5(2), 28-41.

Febriya, S., Pranata, O. H., \& Apriliya, S. (2015). Pengembangan Lembar Kerja siswa pada Materi Keliling Lingkaran dengan Pendekatan Pembelajaran Matematika Realistik. PEDADIDAKTIKA:

Jurnal Ilmiah Pendidikan Guru Sekolah Dasar, 2(2), 259-269.

Fiad, U., Suharto, \& Kurniati. (2017). Identifikasi Kemampuan Literasi Matematika Siswa SMP Negeri 12 Jember dalam Menyelesaikan Soal PISA Konten Space and Shape. Kadikma, 8(1), 72-78.

Haryani, S., Wardani, S., \& Prasetya, A. $T$ (2015). Development of Chemsitry Teacher Professionalism through Pedagogical Content Knowledge Training. Sainteknol, 14(2), 139150.

Kemdikbud. (2017). Matematika SMP/MTs Kelas VIII Semester 2. Jakarta: Kementrian Pendidikan dan Kebudayaan.

Khikmiyah, F., \& Midjan. (2016). Pengembangan Buku Ajar Literasi Matematika untuk Pembelajaran di SMP. Jurnal Silogisme: Kajian Ilmu Matematika dan Pembelajarannya, 1(2), 15-26.

Khoirudin, A., Setyawati, R. D., \& Nursyahida, F. (2017). Profil Kemampuan Literasi Matematika Siswa Berkemampuan Matematis Rendah dalam Menyelesaikan Soal Berbentuk PISA. Jurnal Aksioma, 8(2), 33-42. 
Kusuma, B. J., Wardono, W., \& Winarti, E. R. (2016). Kemampuan Literasi Matematika Peserta Didik pada Pembelajaran Realistik Berbantuan Edmodo. Unnes Journal of Mathematics Education, 5(3), 199-206.

Larasati, Rangga, S., Rianasari, \& Fitri, V. (2017). Mathematical Literacy Profile of Grade VIII Students of SMP Pangudi Luhur 1 Yogyakarta using Pendidikan Matematika Realistik Indonesia Approach. International Journal of Indonesian Education and Teaching (IJIET), 1(1), 62-72.

Lestari, I., Prahmana, R. C. I., \& Wiyanti, W. (2016). Peningkatan Kemampuan Penalaran Matematis Siswa menggunakan Pendekatan Pendidikan Matematika Realistik. Jurnal Inovasi Pendidikan Dasar, 1(2), 45-50.

Mahdiansyah \& Rahmawati. (2014). Literasi Matematika Siswa Pendidikan Menengah: Analisis menggunakan Desain Tes Internasional dengan Konteks Indonesia. Jurnal Pendidikan dan Kebudayaan, 20(4), 452-469.

Mangelep, N. O., \& Kaunang, D. F. (2018). Pengembangan Soal Matematika Realistik berdasarkan Kerangka Teori Program for International Students Assessment. Mosharafa: Jurnal Pendidikan Matematika, 7(3), 455-466.

Maulana, A. \& Hasnawati. (2016). Deskripsi Kemampuan Literasi Matematika Siswa Kelas VIII-2 SMP Negeri 15 Kendari. Jurnal Penelitian Pendidikan Matematika, 4(2), 1-14.

OECD. (2016). PISA 2015 Assesement and Analytical Framework:
Science, Reading, Mathematic and Finacial Literacy. Paris: OECD Publishing.

OECD. (2018). PISA 2015 Results in Focus. New York: Columbia University.

OECD. (2019). Indonesia - Country Note - PISA 2018 Results. https://www-oecdorg.proxy.library.uu.nl/pisa/public ations/PISA2018_CN_IDN.pdf.

Ose, L. (2017). Pengembangan Perangkat Pembelajaran dengan Pendekatan PMR untuk Meningkatkan Hasil Belajar Siswa. Kreano, Jurnal Matematika Kreatif-Inovatif, 8(1), 101-108.

Prahmana, R. C. I. (2017). Design Research (Teori dan Implementasinya: Suatu Pengantar). Jakarta: Rajawali Pers

Purwasih, R., Sari, N., \& Agustina, S. (2018). Analisis Kemampuan Literasi Matematik dan Mathematical Habits of Mind Siswa SMP pada Materi Bangun Ruang Sisi Datar. Jurnal Numeracy, 5(1), 67-76.

Santi, D., Sugiarti, T., \& Kristiana, A. I. (2015). Pengembangan Perangkat Pembelajaran Matematika Realistik pada Pokok Bahasan Lingkaran Kelas VIII SMP. KadikmA, 6(1), 85-94.

Sari, R. H. N. (2015). Literasi Matematika: Apa, Mengapa dan Bagaimana. Prosiding Seminar Nasional Matematika dan Pendidikan Matematika 2015, (Hal. 713-720). Yogyakarta: Universitas Negeri Yogyakarta.

Setyaningsih, H., Wardono, \& Prabowo, A. (2017). Keefektifan Pendekatan PMRI Berbantuan Alat Peraga untuk Meningkatkan Kemampuan Literasi Matematika 
DOI: https://doi.org/10.24127/ajpm.v9i2.2782

Siswa. Unnes Journal of Mathematics Education, 6(1), 4451.

Shoffa, S. (2016). Pengembangan Perangkat Pembelajaran Matematika dengan Pendekatan PMR pada Pokok Bahasan Jajargenjang dan Belahketupat. Didaktis: Jurnal Pendidikan dan Ilmu Pengetahuan, 9(3), 43-58.

Sholahudin, U. (2018). Penerapan Pendidikan Matematika Realistik (PMR) untuk Meningkatkan Kemampuan Literasi Matematika Siswa Kelas IV SDN 03 Cimaung Serang. GAUSS: Jurnal Pendidikan Matematika, 1(1), 6673.

Syawahid, M., \& Putrawangsa, S. (2017). Kemampuan Literasi Matematika Siswa SMP ditinjau dari Gaya Belajar. Beta Jurnal Tadris Matematika, 10(2), 222240.

Tessmer, M. (1993). Planning, and Conducting - Formative Evaluations. London: Kogan Page.
Wahyuni, D., Masykur, R., \& Pratiwi, D. D. (2019). Pengembangan Multimedia Pembelajaran Matematika dengan Pendekatan Matematika Realistik. AKSIOMA: Jurnal Program Studi Pendidikan Matematika, 8(1), 32-40.

Wardono \& Kurniasih, A. W. (2015). Peningkatan Literasi Matematika Mahasiswa Melalui Pembelajaran Inovatif Realistik E-Learning Edmodo Bermuatan Karakter Cerdas Kreatif Mandiri. Jurnal Kreano, 6(1), 93-100.

Wati, T., Zulkardi, \& Susanti, E. (2015). Pengembangan Bahan Ajar PMRI Topik Literasi Finansial pada Aritmatika Sosial Kelas VII. Jurnal Pendidikan Matematika, 9(1), 22-34.

Wijaya, A. (2012). Pendidikan Matematika Realistik: Suatu Alternatif Pendekatan Pembelajaran Matematika. Yogyakarta: Graha Ilmu.

Zulkardi \& Putri, R. I. I. (2010). Pengembangan Blog Support untuk Membantu Siswa dan Guru Matematika Indonesia Belajar Pendidikan Matematika Realistik Indonesia (PMRI). Jurnal Inovasi Perekayasa Pendidikan (JIPP), 2(1), 1-24. 